\title{
Sulfitobacter litoralis sp. nov., a marine bacterium isolated from the East Sea, Korea
}

Correspondence

Yong-Ha Park

peter@yumail.ac.kr

\author{
Ja Ryeong Park, ${ }^{1}$ Jin-Woo Bae, ${ }^{1}$ Young-Do Nam, ${ }^{1}$ Ho-Won Chang, ${ }^{1}$ \\ Hyuk-Yong Kwon, ${ }^{1}$ Zhe-Xue Quan ${ }^{1,2}$ and Yong-Ha Park ${ }^{3,4}$ \\ ${ }^{1}$ Korea Research Institute of Bioscience and Biotechnology (KRIBB), 52 Oeundong, Yusong, \\ Daejeon 305-333, Republic of Korea \\ ${ }^{2}$ Department of Microbiology and Microbial Engineering, School of Life Sciences, Fudan \\ University, Shanghai 200433, China \\ ${ }^{3}$ proBionic Corp., KRIBB, 52 Oeundong, Yusong, Daejeon 305-333, Republic of Korea \\ ${ }^{4}$ Department of Applied Microbiology, Yeungnam University, Kyeongsan-si, Kyeongbuk \\ 712-749, Republic of Korea
}

A Gram-negative, aerobic, halophilic bacterium, designated strain Iso $3^{\top}$, was isolated from the East Sea in Korea. Strain Iso $3^{\top}$ was motile by means of polar flagella, occasionally formed rosette-like aggregates and contained $18: 1 \omega 7 c$ as the dominant cellular fatty acid. Strain Iso $3^{\top}$ grew at $\mathrm{NaCl}$ concentrations of $1-10 \%$ and temperatures of $4-30{ }^{\circ} \mathrm{C}$. The optimal growth temperature was $20^{\circ} \mathrm{C}$. Analysis of the $16 \mathrm{~S}$ rRNA gene sequence revealed that this strain is affiliated with a subcluster of the Alphaproteobacteria. However, strain Iso $3^{\top}$ generated metabolic energy by sulfide oxidation. The $16 \mathrm{~S}$ rRNA gene sequence similarity between strain Iso $3^{\top}$ and the type strain of the most closely related species, Sulfitobacter pontiacus, was 97.7\%. DNA-DNA relatedness between strain Iso $3^{\top}$ and Sulfitobacter pontiacus DSM $10014^{\top}$ was $24.1 \%$. On the basis of phenotypic properties and phylogenetic distinctiveness, strain Iso $3^{\top}$ is classified within a novel Sulfitobacter species, for which the name Sulfitobacter litoralis sp. nov. is proposed, with the type strain Iso $3^{\top}\left(=\right.$ KCTC $12521^{\top}=$ DSM $\left.17584^{\top}\right)$.

Interest in isolation and description of bacterial isolates from the marine environment has increased in recent years (Pukall et al., 1999). According to recently reported data, members of the genus Sulfitobacter are ubiquitous marine bacteria (Ivanova et al., 2004). Strains of the genus Sulfitobacter, which is a member of the Roseobacter group, were first isolated in 1995 from the Black Sea (Ivanova et al., 2004; Sorokin, 1995). Members of the Roseobacter group are abundant in the marine environment (Gonzalez et al., 1999), but many isolates are as yet undescribed. In this study, we describe a Sulfitobacter-like strain, designated Iso $3^{\mathrm{T}}$, which we have characterized by phenotypic, genetic and chemotaxonomic analyses.

Strain Iso $3^{\mathrm{T}}$ was isolated from a water sample from the East Sea in Korea using the dilution plating technique. The strain was grown routinely on marine agar 2216 (MA; Difco) at $20{ }^{\circ} \mathrm{C}$ and replated every 2 days. As reference strains, the most closely related type strains by $16 \mathrm{~S}$ rRNA gene sequence similarity, Sulfitobacter pontiacus DSM $10014^{\mathrm{T}}$, Sulfitobacter

Abbreviation: BChl, bacteriochlorophyll.

The GenBank/EMBL/DDBJ accession number for the 16S rRNA gene sequence of strain Iso $3^{\top}$ is DQ097527. brevis DSM $11443^{\mathrm{T}}$, Sulfitobacter delicatus ATCC BAA- $321^{\mathrm{T}}$ and Sulfitobacter dubius ATCC BAA- $320^{\mathrm{T}}$, were obtained from the DSMZ and the ATCC and grown under the same conditions. The morphology of live cells and the presence of flagella were investigated using light microscopy (Nikon E600) and transmission electron microscopy (TEM). For TEM observations, cells from exponentially grown cultures were negatively stained with $1 \%(\mathrm{w} / \mathrm{v})$ phosphotungstic acid. After air drying, the grid was examined using a model H-7600 transmission electron microscope (Hitachi). Growth at various $\mathrm{NaCl}$ concentrations, temperatures and $\mathrm{pH}$ values was measured in marine broth 2216 (MB; Difco). API 20 NE test strips (bioMérieux) were used to analyse the biochemical and physiological traits of the bacterial strains and standard microbiological methods were used for Gram staining and assessment of motility and enzyme reactions of catalase (with $5 \% \mathrm{H}_{2} \mathrm{O}_{2}$ ) and oxidase. The ability to oxidize sulfite was tested as described by Pukall et al. (1999).

Bacterial strains grown on MA plates at $20^{\circ} \mathrm{C}$ for 2 days were used for fatty acid methyl ester (FAME) analysis. FAMEs were extracted and prepared according to the standard protocol of the MIDI/Hewlett Packard Microbial Identification System (Sasser, 1990). Chromosomal DNA was extracted and purified according to the method 
Table 1. Characteristics that differentiate strain Iso $3^{\top}$ (Sulfitobacter litoralis sp. nov.) from phylogenetically related species

Strains: 1, Iso $3^{\mathrm{T}}$; 2, Staleya guttiformis DSM $11458^{\mathrm{T}}$ (data from Labrenz et al., 2000); 3, Sulfitobacter brevis DSM $11443^{\mathrm{T}}$ (Labrenz et al., 2000); 4, Sulfitobacter pontiacus DSM $10014^{\mathrm{T}}$ (Sorokin, 1995); 5, Sulfitobacter delicatus ATCC BAA-321 ${ }^{\mathrm{T}}$ (Ivanova et al., 2004); 6, Sulfitobacter dubius ATCC BAA-320 ${ }^{\mathrm{T}}$ (Ivanova et al., 2004); 7, Sulfitobacter mediterraneus CH-B427 $7^{\mathrm{T}}$ (Pukall et al., 1999); 8, Oceanibulbus indolifex DSM $14862^{\mathrm{T}}$ (Wagner-Döbler et al., 2004); 9, Roseobacter litoralis DSM 6996 ${ }^{\mathrm{T}}$ (Shiba, 1991); 10, Roseobacter denitrificans DSM $7001^{\mathrm{T}}$ (Shiba, 1991). +, Positive; W, weakly positive; -, negative; ND, no data. The major fatty acid of all strains is $18: 1 \omega 7 c$.

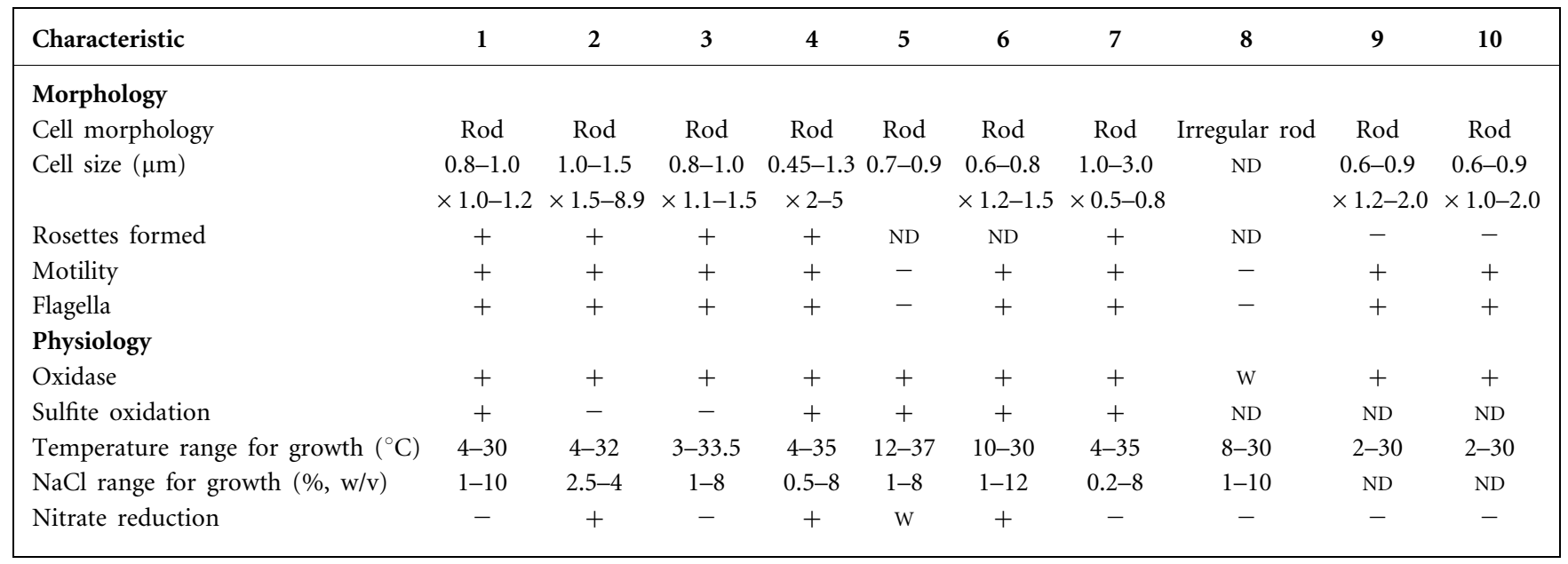

described by Sambrook et al. (1989). The 16S rRNA gene was amplified by PCR using two universal primers, as described previously (Yoon et al., 1998). Sequencing of the amplified 16S rRNA gene and phylogenetic analysis was performed as described by Yoon et al. (2003). DNA-DNA hybridization was performed fluorometrically by the method of Bae et al. (2005) using Cy5-labelled DNA probes and genome-spotted microarrays. The signal produced by self-hybridization was normalized to $100 \%$ and the relative intensities of genomic DNA of other strains were determined as percentage relatedness. The presence of bacteriochlorophyll $a(\mathrm{BChl} a)$ was identified by PCR amplification of the phototrophism-related gene pufM, which encodes the $\mathrm{M}$ subunit of the photosynthetic reaction centre and is distributed universally amongst aerobic phototrophic bacteria (Achenbach et al., 2001; Kim et al., 2006).

Physiological and biochemical characteristics and morphological traits of cells and colonies of strain Iso $3^{\mathrm{T}}$ are shown in Table 1 or are given in the species description. Cells of strain Iso $3^{\mathrm{T}}$ were Gram-negative. They occurred singly or in irregular clusters or rosette-like aggregates. Strain Iso $3^{\mathrm{T}}$ grew at $4-30{ }^{\circ} \mathrm{C}$ (optimum $20^{\circ} \mathrm{C}$ ), in media of $\mathrm{pH}$ 5.0-10.5 (optimum pH 7.0-8.0), but not below $\mathrm{pH} 4.0$ or above $\mathrm{pH} 12.0$, and showed growth in up to $10 \% \mathrm{NaCl}$ (optimum $6.0-7.0 \%)$.

Strain Iso $3^{\mathrm{T}}$ did not reduce nitrate to nitrite. Mannitol, adipate and malate were utilized as sole carbon and energy sources. Glucose, arabinose, mannose, $N$-acetylglucosamine, maltose, gluconate, caprate, citrate and phenylacetate were not utilized. In assays with the API ZYM system, esterase, leucine arylamidase, valine arylamidase and acid phosphatase were present, but alkaline phosphatase, lipase, cystine arylamidase, trypsin, $\alpha$-chymotrypsin, naphtholAS-BI-phosphohydrolase, $\alpha$-galactosidase, $\beta$-galactosidase, $\beta$-glucuronidase, $\alpha$-glucosidase, $\beta$-glucosidase, $N$-acetyl- $\beta$ glucosaminidase, $\beta$-glucosaminidase, $\alpha$-mannosidase and $\alpha$-fucosidase were absent.

The major cellular fatty acids of strain Iso $3^{\mathrm{T}}$ are unsaturated fatty acids such as $18: 1 \omega 7 c(85.6 \%)$ and 11-methyl $18: 1 \omega 7 c(9.1 \%)$ (Table 2$)$. The fatty acid composition was similar to that observed in other members of the genus Sulfitobacter. The presence of $18: 1 \omega 7 c$ as the dominant fatty acid is representative of several major phyletic groups within the Alphaproteobacteria (Labrenz et al., 2000).

Table 2. Fatty acid compositions of strain Iso $3^{\top}$ and related Sulfitobacter type strains

Strains: 1 , Iso $3^{\mathrm{T}}$; 2, Sulfitobacter pontiacus DSM $10014^{\mathrm{T}}$; 3, Sulfitobacter brevis DSM $11443^{\mathrm{T}}$; 4, Sulfitobacter dubius ATCC BAA- $320^{\mathrm{T}}$; 5 , Sulfitobacter delicatus ATCC BAA-321 ${ }^{\mathrm{T}}$. Values are percentages of total fatty acids; -, not detected.

\begin{tabular}{|lcrrrr|}
\hline Fatty acid & $\mathbf{1}$ & $\mathbf{2}$ & $\mathbf{3}$ & $\mathbf{4}$ & $\mathbf{5}$ \\
\hline 3-OH 10:0 & 3.1 & 6.3 & 3.0 & 4.5 & 5.7 \\
3-OH 12:0 & 0.7 & 1.8 & 1.4 & 0.2 & 0.2 \\
3-OH 12:1 & - & - & - & 4.7 & 6.1 \\
$16: 0$ & 4.3 & 6.1 & 17.8 & 10.5 & 7.0 \\
$18: 1 \omega 7 c$ & 85.6 & 73.7 & 63.9 & 64.1 & 59.9 \\
$18: 0$ & - & 0.4 & 2.8 & 0.3 & 0.3 \\
11-Methyl 18: $1 \omega 7 c$ & 9.1 & 5.0 & 1.7 & 13.7 & 6.8 \\
\hline
\end{tabular}




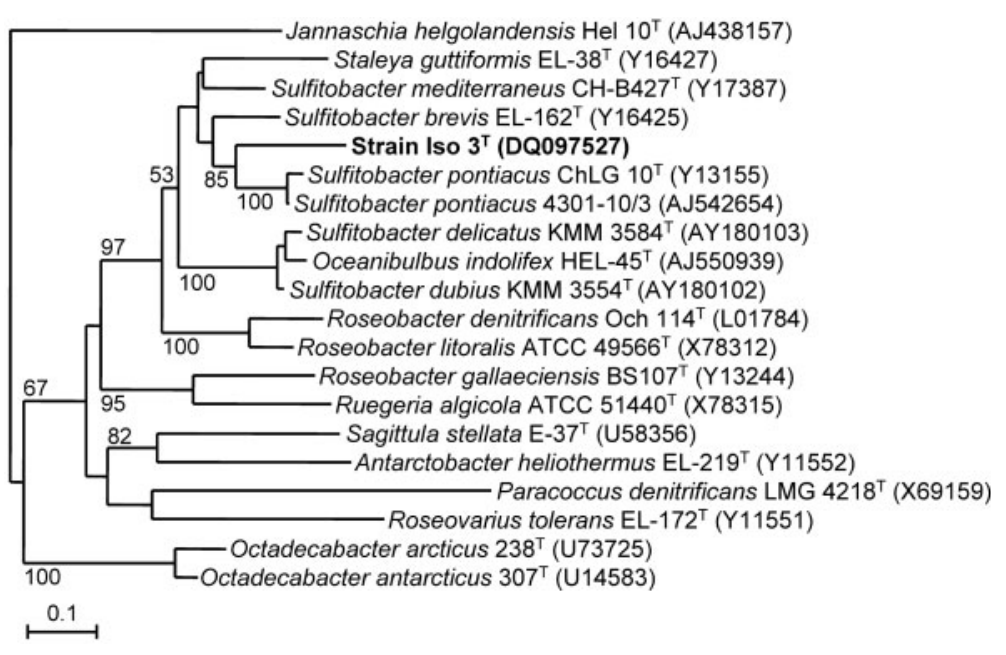

Fig. 1. Neighbour-joining tree based on $16 \mathrm{~S}$ rRNA gene sequences. The tree shows the phylogenetic position of strain Iso $3^{\top}$ relative to closely related strains within the Alphaproteobacteria. Bootstrap percentages (from 1000 replications) $\geqslant 50 \%$ are shown at nodes. Bar, 0.1 substitutions per nucleotide position.
The absence of BChl $a$ is a typical trait among members of the genus Sulfitobacter, and members of the genus generate metabolic energy by sulfite oxidation. Thus, we examined the presence of BChl $a$ and sulfite oxidation activity in Iso $3^{\mathrm{T}}$. Like other members of Sulfitobacter, strain Iso $3^{\mathrm{T}}$ cannot synthesize BChl $a$ to grow photosynthetically under aerobic conditions, but the strain was able to oxidize sulfite.

The 16S rRNA gene sequence of strain Iso $3^{\mathrm{T}}$ determined in this study was 1355 nucleotides in length. Phylogenetic trees based on 16S rRNA gene sequences from members of different genera within the Rhodobacteraceae, including the Sulfitobacter group, showed that Iso $3^{\mathrm{T}}$ falls within the cluster of Sulfitobacter species (Fig. 1). Iso $3^{\mathrm{T}}$ exhibited $16 \mathrm{~S}$ rRNA gene sequence similarities of 97.7-96.8\% to the type strains of four Sulfitobacter species and $96.3 \%$ to Staleya guttiformis DSM $11458^{\mathrm{T}}$. DNA-DNA relatedness between Iso $3^{\mathrm{T}}$ and the most closely related type strains, Sulfitobacter pontiacus DSM $10014^{\mathrm{T}}$, Sulfitobacter brevis DSM $11443^{\mathrm{T}}$, Sulfitobacter dubius ATCC BAA- $320^{\mathrm{T}}$ and Sulfitobacter delicatus ATCC BAA- $321^{\mathrm{T}}$, were respectively 24.1, 5.7, 2.3 and $0.1 \%$, indicating that strain Iso $3^{\mathrm{T}}$ can be considered a member of a novel taxon. Considering the phenotypic, phylogenetic and genotypic characteristics of the isolate, we concluded that Iso $3^{\mathrm{T}}$ belongs to the genus Sulfitobacter. However, based on the phylogenetic and DNA-DNA hybridization data, we propose that Iso $3^{\mathrm{T}}$ should be the type strain of a novel species of the genus, Sulfitobacter litoralis sp. nov.

\section{Description of Sulfitobacter litoralis sp. nov.}

Sulfitobacter litoralis (li.to.ra'lis. L. masc. adj. litoralis of the shore).

Colonies are uniformly round, smooth and slightly yellowish after incubation for $48 \mathrm{~h}$ on MA. Cells are Gramnegative, short rods and are motile by means of polar flagella. Cells occasionally form rosette-like aggregates. Growth occurs at $4-30^{\circ} \mathrm{C}$, with an optimum at $20^{\circ} \mathrm{C}$.
Neutrophilic (pH 5.0-9.0; optimum pH 7.0-8.0). Halophilic; $\mathrm{NaCl}[1.0-10.0 \%(\mathrm{w} / \mathrm{v})$; optimum $6.0-7.0 \%(\mathrm{w} / \mathrm{v})]$ is required for growth. Not able to reduce nitrate. Glucose, arabinose, mannose, $\mathrm{N}$-acetylglucosamine, maltose, gluconate, caprate, citrate and phenylacetate are not utilized, but mannitol, adipate and malate are utilized. Catalase- (with $5 \% \mathrm{H}_{2} \mathrm{O}_{2}$ ) and oxidase-positive. Oxidation of sulfite is observed. BChl $a$ is not produced. The principal cellular fatty acids are $18: 1 \omega 7 c(85.6 \%)$ and 11-methyl $18: 1 \omega 7 c$ $(9.1 \%)$.

The type strain, Iso $3^{\mathrm{T}}\left(=\right.$ KCTC $\left.12521^{\mathrm{T}}=\mathrm{DSM} 17584^{\mathrm{T}}\right)$, was isolated from a water sample obtained from the East Sea, Korea.

\section{Acknowledgements}

This work was supported by grants BDM0200524 and NNM0100512 and the NRL research programme from the Ministry of Science and Technology (MOST) of the Republic of Korea.

\section{References}

Achenbach, L. A., Carey, J. \& Madigan, M. T. (2001). Photosynthetic and phylogenetic primers for detection of anoxygenic phototrophs in natural environments. Appl Environ Microbiol 67, 2922-2926.

Bae, J. W., Rhee, S. K., Nam, Y. D. \& Park, Y. H. (2005). Generation of subspecies level-specific microbial diagnostic microarrays using genes amplified from subtractive suppression hybridization as microarray probes. Nucleic Acids Res 33, e113.

Gonzalez, J. M., Kiene, R. P. \& Moran, M. A. (1999). Transformation of sulfur compounds by an abundant lineage of marine bacteria in the alpha-subclass of the class Proteobacteria. Appl Environ Microbiol 65, 3810-3819.

Ivanova, E. P., Gorshkova, N. M., Sawabe, T., Zhukova, N. V., Hayashi, K., Kurilenko, V. V., Alexeeva, Y., Buljan, V., Nicolau, D. V. \& other authors (2004). Sulfitobacter delicatus sp. nov. and Sulfitobacter dubius sp. nov., respectively from a starfish (Stellaster equestris) and sea grass (Zostera marina). Int J Syst Evol Microbiol 54, $475-480$. 
Kim, B.-C., Park, J. R., Bae, J.-W., Rhee, S.-K., Kim, K.-H., Oh, J.-W. \& Park, Y.-H. (2006). Stappia marina sp. nov., a marine bacterium isolated from the Yellow Sea. Int J Syst Evol Microbiol 56, 75-79.

Labrenz, M., Tindall, B. J., Lawson, P. A., Collins, M. D., Schumann, P. \& Hirsch, P. (2000). Staleya guttiformis gen. nov., sp. nov. and Sulfitobacter brevis sp. nov., $\alpha$-3-Proteobacteria from hypersaline, heliothermal and meromictic antarctic Ekho Lake. Int J Syst Evol Microbiol 50, 303-313.

Pukall, R., Buntefuß, D., Frühling, A., Rohde, M., Kroppenstedt, R. M., Burghardt, J., Lebaron, P., Bernard, L. \& Stackebrandt, E. (1999). Sulfitobacter mediterraneus sp. nov., a new sulfiteoxidizing member of the $\alpha$-Proteobacteria. Int J Syst Bacteriol 49, 513-519.

Sambrook, J., Fritsch, E. F. \& Maniatis, T. (1989). Molecular Cloning: a Laboratory Manual, 2nd edn. Cold Spring Harbor, NY: Cold Spring Harbor Laboratory.

Sasser, M. (1990). Identification of bacteria by gas chromatography of cellular fatty acids. Technical Note 101. Newark, DE: MIDI Inc.
Shiba, T. (1991). Roseobacter litoralis gen. nov., sp. nov., and Roseobacter denitrificans sp. nov., aerobic pink-pigmented bacteria which contain bacteriochlorophyll a. Syst Appl Microbiol 14, 140-145.

Sorokin, D. Y. (1995). Sulfitobacter pontiacus gen. nov., sp. nov. - a new heterotrophic bacterium from the Black Sea, specialized on sulfite oxidation. Microbiology (English translation of Mikrobiologiia) 64, 295-305.

Wagner-Döbler, I., Rheims, H., Felske, A., El-Ghezal, A., FladeSchröder, D., Laatsch, H., Lang, S., Pukall, R. \& Tindall, B. J. (2004). Oceanibulbus indolifex gen. nov., sp. nov., a North Sea alphaproteobacterium that produces bioactive metabolites. Int J Syst Evol Microbiol 54, 1177-1184.

Yoon, J. H., Lee, S. T. \& Park, Y.-H. (1998). Inter- and intraspecific phylogenetic analysis of the genus Nocardioides and related taxa based on 16S rDNA sequences. Int J Syst Bacteriol 48, 187-194.

Yoon, J. H., Kim, H., Kim, I. G., Kang, K. H. \& Park, Y.-H. (2003). Erythrobacter flavus sp. nov., a slight halophile from the East Sea in Korea. Int J Syst Evol Microbiol 53, 1169-1174. 